\title{
Pelatihan Sistem Budidaya Cacing Sutra (Tubifex Sp.) Ramah Lingkungan Di Desa Pudak
}

\author{
Hutwan Syarifuddin *1, Dodi Devitriano ${ }^{2}$, Fauzan Ramadan ${ }^{3}$, A. Yani 4 \\ 1Program Studi Ilmu Lingkungan, Pascasarjana Universitas Jambi \\ 2Program Studi Peternakan, Fakultas Peternakan, Universitas Jambi \\ 3Program Studi Pemanfaatan Sumberdaya Perikanan, Fakultas Peternakan, Universitas Jambi \\ Jl. H.A. Manaf Kampus Unja Telanaipura Jambi 36122 \\ *e-mail: hutwan_syarifuddin@unja.ac.id ${ }^{1}$, devitriano@yahoo.co.id ${ }^{2}$, fauzaramadan@unja.ac.id ${ }^{3}$, \\ ahmadyanimisraini@unja.ac.id ${ }^{2}$
}

\begin{abstract}
Silkworms (Casut) is a natural feed containing nutrients that are good for the growth of fish seeds (burayak). The development of casut cultivation has been carried out by the Sinar Harapan farming group but has not shown satisfactory results, while the demand for casut continues to increase. The resulting casut has not been able to meet the needs due to limited knowledge and skills of casut-making so that the depth of casut cultivation is still quite high. To overcome these obstacles, devotion is carried out to increase the knowledge and skills of members of the peasant group in the cultivation of casut and increase the quantity and quality of the casut produced. The method of casut cultivation given to members of the peasant group is a cultivation system using apartments and water recirculation. Training activities include the manufacture of casut feed, casut quarantine process, casut maintenance and harvesting methods. The results of casut cultivation system training can increase the knowledge and skills of group members based on response by $80 \%$ and the cultivation of casut apartment systems can increase the quantity and quality of environmentally friendly.
\end{abstract}

Keywords: Cultivation, SilkWorm, Pudak Village

\begin{abstract}
Abstrak
Cacing sutra (Casut) merupakan pakan alami mengandung nutrisi yang baik untuk pertumbuhan benih ikan (burayak). Pengembangan budidaya casut telah dilakukan oleh kelompok tani Sinar Harapan tetapi belum menunjukkan hasil yang memuaskan, sedangkan permintaan casut terus meningkat. Casut yang dihasilkan belum mampu memenuhi kebutuhan karena keterbatasan pengetahuan dan ketrampilan pembenih casut sehingga kegagalam budidaya casut masih cukup tinggi. Untuk mengatasi kendala tersebut maka dilakukan pengabdian dengan tujuan meningkatkan pengetahuan dan keterampilan anggota kelompok tani dalam budidaya casut dan meningkatkan kuantitas dan kualitas casut yang dihasilkan. Metode budidaya casut yang diberikan kepada anggota kelompok tani adalah sistem budidaya menggunakan apartemen dan resirkulasi air. Kegiatan pelatihan meliputi pembuatan pakan casut, proses karantina casut, cara pemeliharaan dan pemanenan casut. Hasil pelatihan sistem budidaya casut mampu meningkatkan pengetahuan dan keterampilan anggota kelompok berdasarkan respon sebesar 80\% dan budidaya casut sistem apartemen bisa meningkatkan kuantitas dan kualitas casut ramah lingkungan..
\end{abstract}

Kata kunci: Budidaya, Cacing Sutra, Desa Pudak

\section{PENDAHULUAN}

Budidaya perikanan merupakan salah satu sektor unggulan yang dapat dioptimalkan dalam meningkatkan produksi perikanan nasional. Namun demikian dalam budidaya perikanan masih menghadapi permasalahan mengenai pakan ikan. Pakan yang diberikan baik yang berasal dari bahan baku impor maupun dari pakan alami. Kebutuhan pakan alami terus meningkat pada budidaya ikan. Pakan alami seperti cacing sutra (casut) selama ini hanya diambil dari alam, sehingga ketersediaannya sangat terbatas. Casut dapat dibudidayakan dan diproduksi secara massal dan mandiri

Budidaya casut telah dilakukan oleh kelomok tani Sinar Harapan yang berada di Desa Pudak Kecamatan Kumpeh Ulu Kabupaten Muaro Jambi. Desa Pudak berada pada ketinggian 8$17 \mathrm{~m} \mathrm{dpl}$, dengan luas $16,54 \mathrm{~km}^{2}$, dengan jumlah penduduk sebanyak 1342 orang (BPS, 2020). Desa Pudak memiliki potensi untuk mengembangkan usaha budidaya casut karena kondisi 
lahan yang mendukung dan permintaan yang tinggi terhadap pakan alami dari pembudidaya ikan lele dan ikan nila yang ada di Desa Pudak dan desa lain terutama pada masa pembenihan larva atau benih ikan (burayak). Benih ikan membutuhkan pakan utama berupa casut untuk menunjang pertumbuhannya. Pakan alami (casut) dapat diberikan mulai benih ikan umur 2 sampai 15 hari.

Pembenihan merupakan salah satu kegiatan dalam budidaya ikan yang berhadapan dengan masalah tingkat kematian larva yang tinggi. Kematian larva disebabkan karena ketersediaan pakan baik secara kuantitas dan kualitas tidak sesuai dengan kebutuhan larva. Cacing sutera (Tubifex sp.) merupakan salah satu jenis pakan alami untuk budidaya ikan.

Pengembangan budidaya casut telah dilakukan oleh pembenih di kelompok tani Sinar Harapan tetapi belum menunjukkan hasil yang memuskan. Hal ini disebabkan pengetahuan dan keterampilan (skill) yang belum memadai tentang budidaya cacing sutra, keterbatasan sarana dan prasarana yang tersedia. Umumnya anggota kelompok tani mendapatkan casut dengan cara mengambil langsung dari sungai yang mengandung buangan organik yang tinggi, dan produksi casut sangat berfuktuasi tergantung pada musim hujan dan musim kemarau., sehingga kebutuhan pakan alami untuk larva masih sangat terbatas.

Untuk mengatasi terbatasnya produksi casut maka kelompok tani Sinar Harapan melakukan budidaya casut dengan sistem apartemen yang tersusun vertikal dengan menggunakan resirkulasi air yang mengalir. Keuntungan sistem apartemen yaitu; (1) efisiensi lahan, (2) mengurangi penitrasi cahaya secara langsung, (3) lebih mudah dalam kontrol, dan ( 4) tidak tergantung pada musim. Sedangkan sistem resirkulasi bertujuan untuk mensuplai kandungan oksigen di dalam air media.

Casut merupakan pakan yang sangat popular dan efektif untuk larva atau benih ikan karena kandungan nilai gizi yang tinggi seperti protein, lemak, mineral, vitamin B12, asam amino dan lemak tidak jenuh untuk menenuhi kebutuhan nutrisi bagi pertumbuhan benih ikan. Menurut Syarifuddin dan Devitriano (2020) penggunaan casut dalam budidaya lele dengan metode bioflok dapat mengurangi kematian larva lele. Sebagai contoh untuk menghasilkan 200.000-250.000 ekor benih ikan lele dibutuhkan 2 liter casut (Eddy et al., 2015). Produktivitas casut masih rendah atau di bawah 2,5 kg/m3 (Findy, 2011; Pardiansyah, 2014).

Menurut Bintaryanto dan Taufikurohmah (2013) Casut memiliki kandungan nutrien yang cukup tinggi yaitu protein (57\%), lemak (13,3\%), serat kasar $(2,04 \%)$, kadar abu $(3,6 \%)$. Biomassa casut sebesar $1745,14 \mathrm{~g} / \mathrm{m} 3$ (Suryadin et al., 2017). Casut dapat tumbuh dengan baik pada perairan yang memiliki kandungan bahan-bahan organik tinggi (Haryanti dan Hidajati, 2013) dan dapat beradaptasi pada perairan dengan oksigen terlarut rendah (Marian dan Pandian, 1989). Selain kandungan bahan organik, porositas tanah juga berpengaruh dalam budidaya casut.

Pertumbuhan casut dipengaruhi oleh bakteri dan partikel organik hasil perombakan bakteri sebagai pakan casut (Fajri et al., 2014). Bakteri membutuhkan kandungan C/N yang terdapat dalam media pemeliharaan untuk menghasilkan protein sel, sehingga dimanfaatkan oleh casut untuk pertumbuhannya. Selain itu teknologi fermentasi dapat meningkatkan kandungan nutrisi bahan organik sehingga dapat meningkatkan biomassa dan pertumbuhan casut (Rahman, 2012). Fajri et al., (2014) menggunakan kotoran ayam terfermenasi EM4 dikombinasikan ampas tahu dan tepung tapioka dapat memberikan pertumbuhan biomassa dan pertumbuhan populasi yang lebih optimal dibandingkan dengan kotoran puyuh terfermentasi.

Dalam usaha budidaya casut dapat dilakukan dengan menggunakan bak dan rak vertikal. Sistem apartemen secara vertikal tidak membutuhkan lahan yang luas. Budidaya casut dapat dikerjakan dalam skala rumah tangga atau dikerjakan di sekitar rumah penduduk dengan memanfaatkan lahan seoptimal mungkin. Kebutuhan utama untuk usaha casut adalah sumberdaya air sebagai sirkulasi untuk kehidupan casut. Air yang baik adalah berasal dari air tanah atau dari sumur dangkal tanpa diberi kaporit dengan pH 6-9.

Produktivitas casut yang dibudidayakan oleh kelompok tani Sinar Harapan Desa Pudak dapat terus ditingkatkan karena permintaan konsumen yang tinggi sebagai pakan larva ikan (burayak) dengan harga yang stabil. Tetapi kendala yang masih dihadapi oleh kelompok tani Sinar Harapan adalah masih terbatasnya sumberdaya manusia atau rendahnya pengetahuan 
dan keterampilan (skill), terbatasnya pelatihan, penyuluhan dan pendampingan, masih terbatasnya sarana dan prasarana pendukung, keterbatasan modal dan aplikasi teknologi yang digunakan dalam membudidayakan casut.

Budidaya casut merupakan salah satu usaha ramah lingkungan dan dapat menciptakan keragaman keriwausahaan bagi masyarakat Hal ini menjadi alasan untuk melakukan pelatihan teknologi budidaya casut ramah lingkungan agar dapat memperoleh manfaat bagi pembudidaya casut, pembenih ikan dan masyarakat Desa Pudak serta masyarakat desa lain. Salah satu teknik yang dapat digunakan untuk meningkatkan produktivitas casut adalah dengan tetap menjaga kebersihan lingkungan, menjaga sumber air dan menggunakan sumber pakan yang berkualitas. Tujuannya untuk mempertahankan pertumbuhan dan perkembangan yang berkaitan dengan kuantitas dan kualitas casut.

Pengembangan budidaya casut dengan sistem apartemen dan resirkulasi air dapat menjawab permasalahan pasokan pakan untuk larva ikan agar pertumbuhan larva dan benih ikan tetap terjaga. Kemudian budidaya casut dapat dilakukan dengan teknologi yang sederhana, sebagai diversifikasi usaha, kuantitas dan kualitas casut yang baik, dengan harga yang murah serta efisien dalam pemanfaatan lahan.

Pengabdian kepada masyarakat dilakukan dengan tujuan untuk meningkatkan pengetahuan, dan keterampilan anggota kelompok tani Sinar Harapan dalam budidaya casut dan menningkatkan kuantitas dan kualitas casut (Tubifex sp.) yang dihasilkan.

Keberlanjutan dari budidaya casut diharapkan bisa dilakukan mandiri oleh pembenih ikan baik di Desa Pudak maupun desa lain sehingga ketergantungan terhadap pakan impor bisa dikurangi.

\section{METODE}

Pengabdian kepada masyarakat (PKM) dilaksanakan pada kelompok tani Sinar Harapan Desa Pudak Kecamatan Kumpeh Ulu selama lebih kurang 4 bulan. Peserta sebanyak 15 orang yang berasal dari anggota kelompk tani dan masyarakat di sekitarnya. Sebelum pelaksanaan PKM, maka tim pengabdian sudah melakukan pendekatan dan pembinaan pada anggota kelompok tani. Kegiatan telah dilakukan dari bulan Mei sampai Agustus 2021. Kegiatan dimulai dengan meninjau secara langsung kondisi eksisting wilayah mitra kemudian dilanjutkan dengan menumbuhkan kesadaran anggota kelompok tani dan masyarakat tentang pentingnya mengetahui sistem budidaya casut yang ramah lingkungan. Selanjutnya melakukan sosialisasi program dan kegiatan, pelatihan keterampilan pada anggota kelompok dalam menjaga produktivitas casut. Dilakukan pendampingan dan evaluasi kepada mitra untuk mengamati, menilai tingkat keberhasilan kegiatan dan memberikan solusi terhadap permasalahan yang ditemui dalam budidaya casut.

Metode pendekatan pada anggota kelompok tani dengan cara on farm. Budidaya casut yang ada masih menggunakan peralatan sederhana seperti gallon bekas secara berangsurangsur mulai diganti dengan nampan atau tray plastik yang lebih bersih, selain itu anggota kelompok tani menggunakan sumberdaya lokal berupa ampas tahu yang difermentasi dengan menggunakan EM4, kemudian dengan memberikan pelatihan untuk peningkatan pengetahuan dan keterampilan anggota kelompok tani dengan memperhatikan aspek efisiensi dan efektifitas.

Dalam pelaksanaan PKM ada 3 kegiatan yang dilakukan agar tujuan yang diharapkan bisa tercapai, yaitu: (1) pelatihan cara budidaya casut dengan sistem apartemen dan resirkulasi air, (2) pendampingan budidaya casut, dan (3) pengadaan buku panduan tentang budidaya casut.

Upaya untuk mensukseskan kegiatan PKM melalui pendekatan dengan perangkat desa, dan anggota kelompok tani yang dapat membantu dan melaksanakan kegiatan PKM. Pemilihan kelompok sasaran berdasarkan atas pertimbangan dan permintaan dari aparat desa dan kelompok tani dalam pengembangan usaha budidaya casut ramah lingkungan. Motivasi yang tinggi dari anggota kelompok tani merupakan kelompok sasaran yang memiliki fungsi strategis untuk penyebaran inovasi baru bagi sasaran (masyarakat) yang lebih luas. 
Dalam pelaksanaan PKM dilakukan pengumpulan data sebelum dan sesudah pemberian pelatihan dan demontrasi keterampilan dalam budidaya casut. Semua peralatan dan bahan yang digunakan dalam PKM sebelumnya harus dipersiapkan terlebih dahulu, seperti; persiapan tempat budidaya casut, pembuatan apartemen dan rak (penempatan nampan atau tray), pemilihan bibit casut, penyediaan pakan, obat -obatan dan brower (alat sirkulasi air).

\subsection{Observasi Permasalahan}

Kegiatan observasi dilakukan dengan tujuan untuk mengetahui kondisi kelompok tani Sinar Harapan Desa Pudak mengenai permasalahan dalam budidaya casut. Kegiatan pengabdian kepada masyarakat di awali dengan melakukan pengamatan dan mengunjungi langsung ke lokasi. Setelah mengetahui kondisi permasalahan yang terjadi, maka dapat dilakukan perumusan strategi untuk sistem budidaya casut dengan pelaksanaan terhadap solusi permasalahannya. Kemudian dengan menyusun secara detail rangkaian kegiatan yang akan dilakukan, sehinggga kegiatan dapat berjalan dengan lancar.

2.2. Persiapan Alat dan Bahan

Persiapan alat dan bahan sangat diperlukan untuk pelaksanaan pengabdian kepada masyarakat. Alat dan bahan dipersiapkan untuk persiapan lokasi dan pembangunan rak vertikal mulai dari input, proses dan output dari budidaya casut dan selanjutnya dijadikan sebagai penunjang dalam proses pelaksanaan pengabdian kepada masyarakat. Adapun alat dan bahan seperti rumah casut dengan ukuran $(2 \mathrm{~m} \times 2 \mathrm{~m})$, rak-rak, nampan atau tray ukuran (30 cm X 28,5 cm X 20cm ), brower, instalasi air/pipa paralon, nutrisi atau pakan casut, obatobatan casut, sumber air, dan bibit casut. Budidaya casut dengan sistem apartemen dan resirkulasi air tidak membutuhkan lahan yang luas karena media bisa disusun secara vertikal dan cenderung bisa juga diterapkan dilahan yang sempit.

2.3. Sosialisasi dan Pelatihan Keterampilan

Sosialisasi dilakukan berupa pengenalan mengenai sistem budidaya casut kepada anggota kelompok tani dan masyarakat di Desa Pudak. Kegiatan sosialisasi dilakukan secara langsung. Hal ini berfungsi untuk mengenalkan kepada anggota kelompok tani dan masyarakat mengenai rencana kegiatan pengabdian kepada masyarakat, pelatihan memilih bibit casut, pelatihan membuat pakan casut dan pemberian obat-obatan untuk casut, pelatihan perawatan dan pemeliharaan casut sampai panen, serta pelatihan pemasaran casut.

Dampak dari budidaya casut sudah diperoleh anggota kelompok tani. Pada awalnya peternak hanya mencoba membudidayakan casut disamping pekerjaan utama sebagai petani. Banyak kegagalan yang diperoleh tetapi dengan ketekunan dan kesabaran untuk mengikuti pelatihan maka saat ini pembudidaya casut sudah menemukan cara yang tepat untuk berusaha. Pembudidaya casut sudah mulai memanfaatkan lahan pekarangan menjadi lebih produktif dengan membangun rak-rak untuk casut. Hasil dari budidaya casut dapat menambah pendapatan keluarga anggota kelompok tani. Keberlanjutan dari budidaya casut dapat tercapai melalui penyediaan bibit yang baik, pakan yang berkualitas, lingkungan yang mendukung dalam kewirausahaan dan jaminan pasar (supply and demand).

Ketercapaian kegiatan PKM dapat dicerminkan dari partisipasi aktif dan perubahan sikap anggota kelompok tani, dimulai dari perencanaan kegiatan, pelaksanaan, monitoring dan evaluasi, serta tindakan yang diambil untuk membuat suatu keputusan dalam berusaha. Walaupun usaha budidaya casut bukan usaha utama namun usaha casut sangat menjanjikan untuk kelompok sasaran pada masa mendatang karena harga jual yang stabil dan pemeliharaan tidak terlalu sulit untuk dilakukan oleh anggota kelompok tani sehingga memberikan keuntungan pada kelompok mitran. Survei lokasi tempat budidaya casut dan diskusi rencana kegiatan pengabdian kepada masyarakat dapat dilihat pada Gambar 1, Gambar 2 dan Gambar 3. 


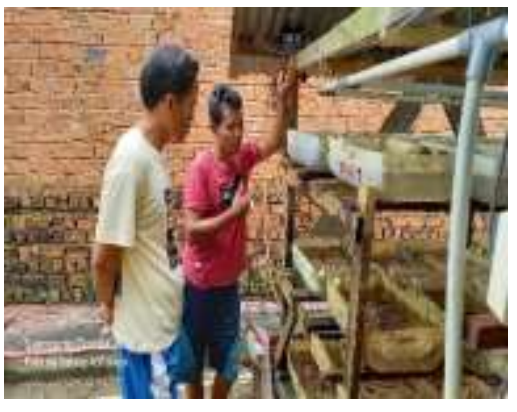

Gambar 1. Survei awal

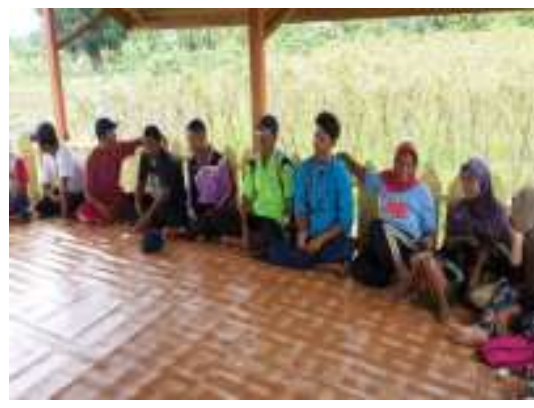

Gambar 2. Diskusi program PKM

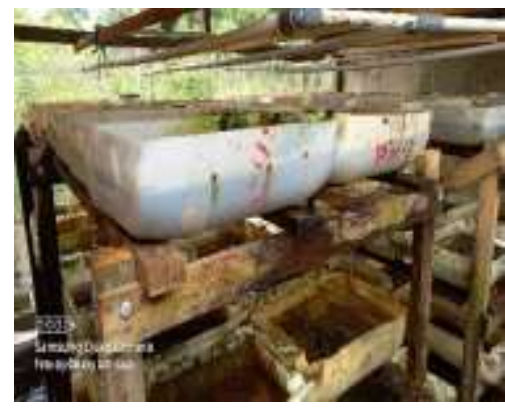

Gambar 3. Contoh rak casut

\section{HASIL DAN PEMBAHASAN}

Kegiatan budidaya casut pertama sekali dilakukan oleh anggota kelompok tani Sinar Harapan melalui pembuatan tempat penampungan bibit casut yang diambil dari alam atau perairan sungai kemudian dipindahkan ke dalam bak terpal. Menurut Suryadin et al., (2017) Cacing sutra yang ditangkap dari alam tidak memiliki jaminan kualitas baik, semakin banyak kandungan bahan tercemar di alam maka akan semakin banyak bahan tercemar terakumulasi di dalam tubuh casut. Tujuan penampungan casut ke dalam bak terpal agar bibit casut mampu beradaptasi pada tempat budidaya, terhindar dari logam berat dan terhindar dari predator seperti cacing darah kemudian untuk mempermudah dalam perawatan casut. Setelah dilakukan adaptasi selama satu bulan maka casut dipindahkan ke dalam nampan atau tray yang tersusun dalam bentuk apartemen dengan rak-rak dan diberi air dengan sirkulasi mengalir dari bagian atas ke bagian bawah. Casut setiap hari diberi pakan berupa ampas tahu yang difermentasi dengan EM4 ditambah gula atau molases. EM4 diaktifkan terlebih dahulu dengan air dan gula atau molases dengan perbandingan $50 \mathrm{ml}$ air, $1 \mathrm{ml}$ EM4 dan $1 \mathrm{ml}$ gula atau molasses. Tujuan fermentasi ampas tahu untuk meningkatkan kandungan $\mathrm{N}$-organik dan C-organik.

Pengontrolan rak, tray dan sirkulasi air dilakukan setiap hari terutama dalam menjaga kebersihan lingkungan tempat budidaya casut. Untuk mengalirkan air mulai dari rak tertinggi dengan menggunakan alat brower, sehingga sirkulasi air dan udara yang masuk ke dalam tray tetap terjaga, kondisi air harus selalu bersih dengan pH air 6 - 9. Selain ketersediaan air, pakan casut juga merupakan faktor penting untuk diperiksa setiap hari agar pertumbuhan dan perkembangbiakan casut meningkat. Pemberian pakan dalam bentuk ampas tahu yang telah difermentasi dengan EM4 dan molasses sebanyak 2 sendok makan untuk setiap tray per hari. Sebagai pakan casut dapat juga digunakan buah atau sayuran, feses burung puyuh ataupun feses ayam yang dimasukkan ke dalam tray. Tetapi yang baik adalah pakan dari ampas tahu fermentasi (Chilmawati et al., 2014), hal ini dicerminkan dari pertumbuhan dan perkembangbiakan casut lebih ccpat.

Dalam pemeliharaan casut tidak terlepas dari hama penyakit dan predator. Solusi yang dilakukan untuk mengatasi penyakit casut adalah dengan menjaga kondisi air tetap bersih, $\mathrm{pH}$ air tetap terjaga dan temperatur air sesuai dengan temperatur ruang atau lingkungan (tidak boleh terlalu dingin maupun panas). Menurut Effendi (2013) kisaran normal pH air 5,5-8 dan DO 2,5-7 (mg/l). Pengelolaan air dilakukan untuk memastikan jalannya sistem sirkulasi. Temperatur berpengaruh pada hasil panen casut. Menurut Suryadin et al., (2017) temperatur air selama 45 hari pemeliharan casut minimum $27^{\circ} \mathrm{C}$ dan maksimum sebesar $36^{\circ} \mathrm{C}$.

Proses pemanen dapat dilakukan setelah casut dipelihara selama 2 bulan, Panen casut dilakukan secara rotasi tujuannya untuk menjamin keberlanjutan usaha. Hasil panen dari budidaya casut saat ini baru memenuhi kebutuhan pembenih ikan sebesar $10 \%$, hal ini berkaitan dengan jumlah casut yang masih terbatas sementara itu permintaan dari pembenih ikan (burayak) terus meningkat. Untuk melakukan panen casut menggunakan canting yang dilakukan 3 hari sekali, dan setiap tray dapat menghasilkan satu canting casut, dengan harga jual Rp 20000 per canting. 
Hasil kegiatan pengabdian kepada masyarakat (PKM) menunjukan adanya peningkatan pengetahuan dan keterampilan dari anggota kelompok tani Sinar Harapan untuk melakukan budidaya casut. Indikator ketercapaian tujuan pengabdian adalah $80 \%$ anggota kelompok tani memahami sistem budidaya casut. Dalam menambah pengetahuan tentang budidaya casut, maka anggota kelompok sudah mendapatkan pelatihan singkat dan demontrasi cara budidaya casut. Menurut Hanisa dan Malik (2021) keberhasilan dalam menjalankan suatu usaha dipengaruhi oleh faktor pengetahuan dan motivasi berwirausaha. Pengetahuan meliputi pengetahuan tentang usaha yang akan dibangun, cara menjalankan usaha, manajemen usaha, operasional dan strategi pemasaran yang baik.

Hasil pelatihan budidaya casut telah mendorong partisipasi anggota kelompok untuk membuat tempat budidaya casut dalam bentuk apartemen atau rak sederhana dari kayu yang disusun bertingkat dengan luas $2 \mathrm{~m}$ X $2 \mathrm{~m}$. Kemudian tiang-tiang apartemen dibuat dari besi agar tahan lama dan mudah dalam perawatan. Masing-masing rak dilengkapi dengan instalasi air menggunakan paralon $1 / 2$ inci yang dilengkapi dengan brower untuk mengatur pergerakan air dari tingkat yang lebih tinggi menuju ke rak yang lebih rendah. Pada masing-masing rak ditempatkan nampan atau tray plastik ukuran $30 \mathrm{~cm} \mathrm{X} \mathrm{28,5} \mathrm{cm} \mathrm{X} 20 \mathrm{~cm}$ untuk menampung casut. Masing-masing tray bersisi 10 gram bibit casut.

Bibit casut yang sudah beradaptasi dan ditempatkan di dalam tray diberi pakan dari ampas tahu fermentasi. Pemberian pakan bertujuan untuk mempercepat pertumbuhan dan perkembangbiakan casut, dan agar casut tidak mengkonsumsi logam berat yang dapat membahayakan bagi larva ikan yang menkonsumsi casut (Santoso dan Hernayanti, 2004). Keunggulan yang ada di lokasi PKM adalah tersedia sumberdaya air secara terus menerus dengan pH 6-9, hal ini sesuai dengan Peraturan Pemerintah No 82 Tahun 2001 tentang pengelolaan kualitas air dan pengendalian pencemaran air.

Ampas tahu terfermentasi berasal dari ampas tahu yang diberi EM4 dan gula atau molases kemudian difermentasikan selama tiga hari secara anaerob. Setelah proses fermentasi maka ampas tahu dapat diberikan sebagai pakan casut. Ampas tahu fermentasi lebih awet atau tahan lama bila dibandingkan dengan ampas tahu tanpa fermentasi. Dalam budidaya casut pakan menjadi faktor penting yang harus diperhatikan selain dari faktor lingkungan. Adipu et al., (2019) menyatakan bahwa fermentasi menggunakan gula aren sebagai sumber karbohidrat dapat meningkatkan kelangsungan hidup dan rasio konversi pakan. Kemudian hasil penelitian (Anis et al., 2019) menunjukkan bahwa pemberian EM4 hasil kultur dalam media yang berbeda pada pakan ikan lele berpengaruh secara signifikan terhadap pertumbuhan spesifik/spesific growth rate (SGR), rasio konversi pakan/feed conversion ratio (FCR) dan tingkat kelangsungan hidup/survival rate (SR) benih ikan lele. Proses kegiatan budidaya casut dapat dilihat pada Gambar 4, Gambar 5 dan Gambar 6.

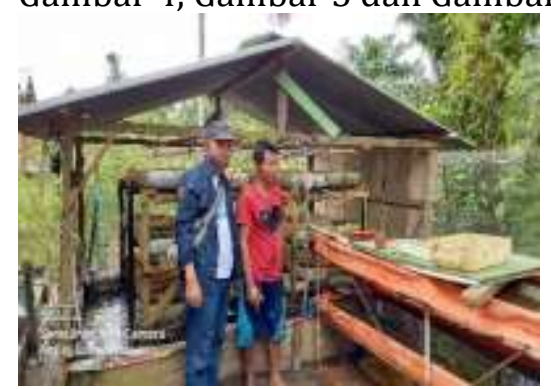

Gambar 4. Tempat adaptasi Casut

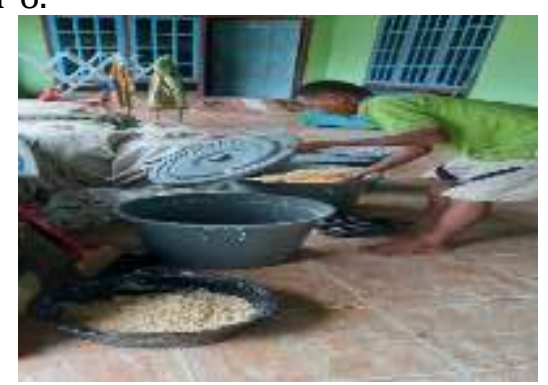

Gambar 5. Pembuatan Pakan casut

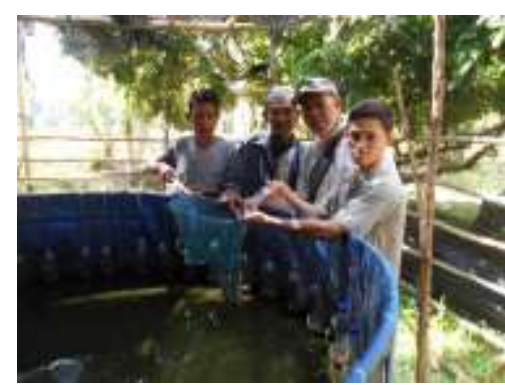

Gambar 6. Casut sebagai pakan burayak

Dalam pelaksanaan kegiatan PKM menunjukkan bahwa partisipasi anggota kelompok tani sangat tinggi dalam mengadopsi pengetahuan cara membudidayakan casut. Untuk meningkatkan kuantitas dan kualitas casut maka tim PKM telah menggantikan tray dari gallon bekas dengan tray yang lebih baik, dan membangun bak permanen untuk tempat rak-rak apartemen, kemudian memberikan pelatihan pembuatan pakan casut, melakukan monitoring dan evaluasi dari setiap kegiatan. 
Budidaya casut sudah mulai merubah persepsi masyarakat dan memberikan motivasi untuk berwirausaha sebagai usaha sampingan dan dapat menambah pendapatan keluarga. Peluang usaha casut cukup menjanjikan karena masa pemeliharaan yang tidak memakan waktu yang lama sehingga perputaran uang cenderung lebih cepat. Pendapatan yang diperoleh anggota kelompok tani sebelum membudidayakan casut hanya bersumber dari pekerjaan pokok seperti bertani, tukang ataupun membuka bengkel. Tetapi setelah membudidayakan casut, maka pendapatan dapat diperoleh dari hasil panen casut yang dibeli pembenih ikan sebagai pakan larva ikan (burayak). Harga per canting casut adalah Rp. 20.000,- dan setiap tray akan menghasilkan satu canting per tiga hari. Anggota kelompok yang memiliki 50 tray akan melakukan panen secara rotasi, dalam tiga hari sekali hanya di panen 5 tray sehingga mendapat 5 canting casut. Masa pertumbuhan casut selama dua minggu sehingga panen dapat dilakukan secara berurutan setiap minggu. Pendapatan harian yang diperoleh anggota kelompok yang sudah membudidayakan casut adalah Rp 100.000,- per tiga hari sebagai pendapatan tambahan.

Dari hasil yang diperoleh anggota kelompok tani maka kegiatan PKM telah memberikan motivasi, menambah pengetahuan dan pengalaman untuk terus berwirausaha. Anggota kelompok tani tetap menginginkan keberlanjutan dalam pembinaan dan pendampingan, sehingga kuantitas dan kualitas hasil budidaya casut terus meningkat dan menjalin kerjasama dengan mitra dalam pemasaran hasil.

Upaya yang dilakukan dalam peningkatan kuantitas dan kualitas casut adalah dengan terus melakukan pendampingan dan monev secara rutin, menjaga lingkungan tempat budidaya casut tetap bersih dan tidak dimasuki oleh predator, menambah jumlah rak-rak untuk tray, memilih bibit casut yang baik, membuat pakan casut yang berkualitas, menjaga kondisi air yang stabil, dan pemeliharaan kesehatan casut. Menurut Tuan dan Soesanti (2017) budidaya casut untuk penyediaan pakan burayak secara swadaya akan memberikan keuntungan, seperti penurunan biaya pembenihan ikan, penurunan ketergantungan pembenih terhadap pakan pabrikan dan peningkatan nilai limbah pertanian dengan memanfaatkannya sebagai bahan pakan.

Selain meningkatkan produktivitas casut, kegiatan PKM juga membangun kerjasama dengan berbagai stakeholder untuk pemasaran casut dan memanfaatkan berbagai sumberdaya alam yang ada di Desa Pudak. kerjasama yang telah dibangun dengan perguruan tinggi, dinas pertanian, pembenih ikan dan pihak swasta, tujuannya agar budidaya casut bisa mandiri dan berkelanjutan.

\section{KESIMPULAN}

Hasil kegiatan pengabdian kepada masyarakat melalui pemberian pelatihan budidaya casut dengan sistem apartemen dan resirkulasi air yang ramah lingkungan telah menambah pengetahuan dan keterampilan anggota kelompok tani sebesar $80 \%$ dan meningkatkan kuantitas dan kualitas hasil casut.

\section{UCAPAN TERIMA KASIH}

Terima kasih kepada Rektor Universitas Jambi, Ketua Lembaga Penelitian dan Pengabdian Pada Masyarakat, Direktur Pascasarjana UNJA, yang telah memberikan bantuan dana dan Ketua Kelompok Tani Sinar Harapan Desa Pudak Kecamatan Kumpeh Ulu yang telah menyediakan fasilitas sehingga pengabdian ini dapat dilaksanakan.

\section{DAFTAR PUSTAKA}

Adipu, Y., Lumenta, C., Mangindaan, R.E.P., \& Manoppo, H. (2019). Growth performance of Litopenaeus vannamei grown in biofloc system produced from different carbohydrate sources. AACL Bioflux, 2019, Volume 12, Issue 2, 472-479. 
Anis, M.Y., \& Hariani, D. (2019). Pemberian pakan komersial dengan penambahan EM4 (Effective Microorganisme 4) untuk Meningkatkan Laju Pertumbuhan Lele (Clarias sp.) . Jurnal Riset Biologi dan Aplikasinya, 1 (1), 1-8. e-ISSN: 2655-9927.

Bintaryanto, B.W., \& Taufikurohmah, T. (2013). Pemanfaatan Campuran Limbah Padat (Sludge) Pabrik Kertas dan Kompos Sebagai Media Budidaya Cacing Sutra (Tubifex sp). UNESA Journal of Chemistry, 2 (1), 1-7.

BPS Kabupaten Muaro Jambi. (2020). Kecamatan Kumpeh Ulu Dalam Angka. Katalog 1102001.1505020. ISSN : 2745-3669.

Chilmawati, D., Suminto \& Tristiana, Y. (2014). Pemanfaatan Fermentasi Limbah Organik Ampas Tahu, Bekatul dan Kotoran Ayam untuk Peningkatan Produksi Kultur dan Kualitas Cacing Sutera (Tubifex sp). Journal of Aquacultur Management and Technology, 3 (4), 186-201.

Eddy, S., Pardiansyah, D., Putri, D. S., \& Djokosetianto, D. (2015). Perbandingan jumlah bak budidaya cacing sutra (tubificidae) dengan memanfaatkan limbah budidaya ikan lele (Clarias sp) sistem intensif terhadap kualitas air ikan lele dan produksi cacing sutra. Depok, 4 (1), 8-14. ISSN 2089-7790, DOI: http://dx.doi.org/10.13170/depik.1.1.2279

Effendi, M. (2013). Beternak cacing sutra cara modern. Penebar Swadaya. Jakarta.

Fajri, N.W., Suminto., \& Hutabarat, J. (2014). Pengaruh penambahan kotoran ayam, ampas tahu dan tepung tapioka dalam media kultur terhadap biomassa,populasi dan kandungan nutrisi cacing sutera (Tubifex sp.). Jour. of Aquaculture Manag. And Tech,. 3(4), 101-108.

Findy, S. (2011). Pengaruh tingkat pemberian kotoran sapi terhadap pertumbuhan biomassa cacing sutra (Tubificidae). IPB. Bogor.

Hanisa., \& Malik. A. (2021). Pengaruh Pengetahuan Dan Motivasi Berwirausaha Terhadap Keberhasilan Usaha Di Kelurahan Jenggi Kecamatan Perbaungan Kabupaten Serdang Bedagai. Jurnal Tijarah, 2 (22), 13-21.

Haryanti, D. N., \& Hidajati, N. (2013). Pengaruh metode pengeringan terhadap kualitas tepung cacing sutra (tubifex sp.)(effect of drying method of wheat quality silk worms (tubifex sp.)). UNESA Journal of Chemistry, 2 (3),71-76.

Marian, M.P., \& Pandian, T. J. (1989). Culture and harvesting technique for Tubifex tubifex. Aquaculture, 42: 303-315.

Pardiansyah, D. (2014). Pemanfaatan limbah budidaya lele (Clarias sp) sistem bioflok untuk budidaya cacing sutra (Tubificidae). [Tesis]. Fakultas Perikanan dan Ilmu Kelauan.Institut Pertanian Bogor. Bogor.

Rahman, W.J. (2012). Efektivitas penggunaan berbagai pupuk kandang yang difermentasi pada budidaya cacing sutra oligochaeta. Departemen Budidaya Perairan, Fakultas Perikanan dan Ilmu Kelautan, Institut Pertanian Bogor, Bogor.

Santoso, S., \& Hernayanti. (2004). Cacing sutra sebagai bio monitor pencemaran logam berat kadmium dan seng dalam leachate TPA sampah Gunung Tugel Purwokerto. Program Studi Biologi. ITS. Surabaya.

Suryadin. D., S. Hemiati., \& Rustadi. (2017). Pengaruh ketebalan media budidaya cacing sutra (Tubifex sp.) menggunakan lumpur limbah budidaya lele. Jurnal Perikanan Universitas Gadjag Mada, 19 (2), 97-105.

Syarifuddin, H., \& Devitriano, D. (2021). Pelatihan Teknik Budidaya Lele Organik Dengan Metode BRL Di Desa Lopak Aur. Jurnal Dinamisa, 5(3), 599-607 DOI: https://doi.org/10.31849/dinamisia.v5i3.6452. P-ISSN 2614-7424 | E-ISSN 2614-8927

Tuan, L. S., \& Soesanti, A. (2017). Application of A Rack Culture System For Tubifex Worms Farming At Pungpungan Village, Bojonegoro. Jurnal Sinergitas PKM \& CSR, 2 (1), 3241,P-ISSN: 2528-7052. 